Jurnal Konstruksi Hukum | ISSN: XXXX | E-ISSN: XXXX Vol. 1, No. 1, September 2020 Hal. 130-134| Available online at https://www.ejournal.warmadewa.ac.id/index.php/jukonhum DOI: https://doi.org/10.22225/jkh.1.1.2145.130-134

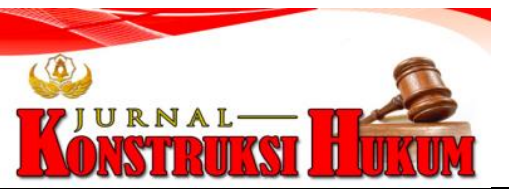

\title{
KEDUDUKAN ALAT BUKTI WEBSITE DALAM PENANGANAN TINDAK PIDANA TERORISME (STUDI PUTUSAN NOMOR 140/PID.SUS/2018/PN.JKT.SEL)
}

\author{
Gemaya Wangsa, Anak Agung Sagung Laksmi Dewi, I Wayan Arthanaya \\ Fakultas Hukum Universitas Warmadewa, Denpasar-Bali, Indonesia
}

\begin{abstract}
Abstrak
Perkembangan teknologi informasi serta korespondensi mengakibatkan tergesernya format media cetak ke media digital, sehingga pertumbuhan itu diikuti oleh kelanjutan perkembangan golongan kejahatan baru yang menunggangi media digital pada aksi pidana terorisme. Penelitian ini bertujuan untuk mengetahui pengaturan penggunaan alat bukti website serta kedudukan penggunaan alat bukti website dalam penanganan tindak pidana terorisme pada kasus perkara nomor 140/Pid.Sus/2018/PN.Jkt.Sel. Penelitian ini menggunakan metode eksplorasi hukum normatif yang datanya bersumber dari determinasi terkait dengan penggunaan alat bukti website dalam Pasal 184 Kitab Undang-undang Hukum Acara Pidana. Hasil penelitain menunjukkan bahwa determinasi eksploitasi alat bukti website yang manakala berdasarkan pada Pasal 184 KUHAP, maka bahan elektronik tak tergolong ke dalam klasifikasi piranti petunjuk yang abash, akan tetapi apabila berpatokan pada peraturan perundang-undangan dalam tindak pidana khusus maka media bukti elektronik mengantongi resistensi sebagai alat bukti yang sah, hal ini dapat dilihat dalam ketentuan Pasal 5 ayat (1) UU ITE yang dipertegas kembali pada bunyi ketentuan Pasal 44 UU ITE. Pendayagunaan alat bukti elektronik dalam proses pembuktian dipersidangan bersumber alat bukti website dalam penegakan hukum tindak pidana terorisme pada skandal Perkara Nomor 140/Pid.Sus/2018/PN.Jkt.Sel dapat dicermati bahwa penggunaan alat bukti website yang secara dogmatis belum diatur pada ketentuan Hukum Acara Pidana khusunya Pasal 184 KUHAP, namun bercorong pedoman peradilan bahwa hakim tidak bisa menangkal untuk menjajaki dan memutus ihwal yang diajukan terhadapnya dengan kilah hukumnya tidak jelas atau tidak ada, selanjutnya kaidah hakim hendaklah membongkar arti hukum lanjut dan berkelajutan di dalam konsorsium, hingga ketentuan sebagaimana dimuat dalam UU ITE yang menata instrument petunjuk elektronik selaku peranti petunjuk yang absah.
\end{abstract}

Kata Kunci: Alat bukti; Website; Tindak pidana terorisme

\begin{abstract}
The development of information technology and correspondence resulted in a shift in the format of print media to digital media, so that this growth was followed by the continuation of the development of a new criminal class that rode digital media in criminal acts of terrorism. This study aims to determine the regulations for the use of website evidence and the position of using website evidence in handling terrorism crimes in case number 140 / Pid.Sus / 2018 / PN.Jkt.Sel. This research uses a normative legal exploration method whose data comes from the determination related to the use of website evidence in Article 184 of the Criminal Code. The results of the research show that the determination of the exploitation of website evidence, which when based on Article 184 of the Criminal Procedure Code, means that electronic material is not classified as an abash instructional device classification, but if it is based on statutory regulations in a special crime, the electronic evidence media has resistance as a valid evidence, this can be seen in the provisions of Article 5 paragraph (1) of the ITE Law which are reaffirmed in the provisions of Article 44 of the ITE Law. Utilization of electronic evidence in the process of evidence in court is sourced from website evidence in law enforcement for criminal acts of terrorism in the Case Number 140 / Pid.Sus / 2018 / PN.Jkt.Sel scandal. Criminal Procedure, especially Article 184 of the Criminal Procedure Code, but has a judicial guideline that the judge cannot refuse to explore and decide the matters brought against him, provided that the law is unclear or non-existent, then the judges' rules should expose the meaning of continued and continuous law in the consortium, up to the provisions as contained in the ITE Law which regulates electronic instruction instruments as valid instruction devices.
\end{abstract}

Keywords: Evidence; Website; Terrorism Crime

I. PENDAHULUAN

Motif kerangka justifikasi cita-cita bangsa Negara Kesatuan Republik Indonesia yakni melindungi semesta bangsa Indonesia dan seluruh mencurah darah Indonesia dan meningkatkan kesentosaan 
masyarakat umum, mencerdaskan kehidupan bangsa dan ikut menunaikan ketertiban dunia yang berpijak atas perdamaian kekal dan keadilan sosial. Masyarakat Indonesia saat ini sedang dihadapkan atas suasana yang sungguh-ungguh menggerunkan akibat semakin maraknya praktik teror. Terorisme mencorakkan kepasikan luar biasa dan pelanggaran berat Hak Asasi Manusia, terpenting hak yang paling falsafah yakni hak untuk hidup yang diatur dalam pasal 28 A Undang - undang Dasar Negara Republik Indonesia Tahun 1945 yang menyatakan bahwa, setiap orang mempunyai hak untuk hidup serta mempunyai hak membentengi kehidupannya. Sebutan teroris dan terorisme berpangkal dari kata latin terrere yang memiliki arti memberikan rasa takut, gemetar, atau menggetarkan.

Hakikat dasarnya sebutan terorisme menggambarkan suatu konsep yang mempunyai implikasi atau sugesti yang rentan disebabkan terorisme menimbulkan tampak korban manusia awam yang tak berdosa (Adji, 2001). Terorisme yaitu kebiadaban kepada manusia yang tidak memiliki rasa kemanusiaan dan pertumbuhan kultur dengan juga membentuk satu intimidasi genting terhadap independensi setiap negara sebab terorisme telah mencorakkan kekejaman yang berkarakter antarbangsa yang membawa dampak bencana terhadap ketentraman, pemufakatan dunia dan juga mudarat kesentosaan masyarakat sehingga mesti dilakukan pemberantasan selaku berkonsep dan berkelanjutan sehingga hak dasar manusia banyak bisa dilindungi dan dijungjung tinggi. Untuk mencapai intensi-intensi oleh itu pemerintah hendaklah memelihara dan memancangkan kedaulatan serta memberi perlindungan setiap orang yang terdapat di negara dari setiap kerawanan gaham atau tindakan yang berasal dari analitis negeri maupun luar negeri yang memberikan dampak yang sangat buruk bagi warganya.

Kemajuan pesat teknologi informasi dan komunikasi berefek pada pergeseran bentuk media cetak kedalam bentuk media digital sehingga kelamajuan itu juga diikuti dengan adanya perkembangan kejahatan baru yang menunggangi media digital, dan ini memiliki partikularitas khusus yang memberikan perbedaan seraya kejahatan awam. Salah satu personalitas khusunya ada atas petunjuk kejahatan berbasis sarana digital berselisih memakasi alat bukti atas kejahatan bersahaja. Tindak kriminal dalam sarana teknologi informasi bersama-sama mengerjakan siasat elektronik sehingga berpotensi menyulut kerugian yang kian besar, terperlus yang berintensitas tinggi seperti halnya pada tindak pidana terorisme.

Determinasi hukum dalam mekanisme pengukuhan kejahatan pada aspek teknologi informasi patut dilaksanakan sehingga penegak hukum dalam proses persidangan melalui pembuktian pada persidangan sehingga terdakwa bisa bertanggung jawabkan seluruh kelakuan yang telah dilakukan. Determinasi Pasal 28 ayat (1) Undang - Undang Nomor 4 Tahun 2004 tentang Kekuasaan Kehakiman (berikut disingkat UU Kekuasaan Kehakiman) tersebut mempersembahkan celah terhada situs dalam website mempu dipergunakan laksana alat bukti petunjuk seraya penegakan hukum pada mekanisme persidangan sehingga nisa dinyatakan menenung mengantongi kekuatan hukum serta diakui keberadannya. Selaku alat bukti pada mekanisme pembuktian pada persidangan lalu sebagaimana diketahui bahwa pembuktian merupakan acuan utama pumpunan pemeriksaan perkara persidangan.

Marbun menerangkan bahwa intensi dari pembuktian yaitu menampakkan alat - alat bukti tertentu kepada hakim sehingga mampu menganjuran kepastian bagi para mejelis hakim akan adanya petunjuk - petunjuk hukum yang disengketakan untuk kemudian dijadikan serupa dengan kausa pertimbangan pada proses pengambilan keputusan (Marbun, 2003). Salah satu kasus tindak pidana yang luang terjadi di Indonesia dan telah diputus dalam persidangan ialah sebagaimana pada ihwal kasus nomor 140/Pid.Sus/2018/PN.Jkt.Sel. Atas inti dakwaan kedua subsidiar tersebut bahwa analitis ikhtiar melancarkan ikrarnya untuk menciptakan wadah tunggal pengikut Daulah Khilafah di Indonesia bersama memperluas pemahaman terkait syirik akbar atau syirik sebagaimana tulisannya dalam buku Seri Materi Tauhid, dimuat dalam blog yang bernama Millah Ibrahim (www.millahibrahim.wordpress) agar mampu disebarluaskan kepada para pengikut atau jamaahnya sebab dapat diakses dengan bebas dan gampang melalui sarana internet.Sehingga bersendikan alat bukti website tersebut yang termuat dalam proses persidangan berlangsung maka sebagaihalnya dalam putusan pada perkara kasus nomor 140/Pid.Sus/2018/PN.Jkt.Sel bahwa terdakwa dinyatakan terbukti secara meyakinkan oleh hakim. Pasal 184 KUHAP yang memaklumatkan 
bahwa alat bukti yang sah ialah keterangan saksi, keterangan ahli, surat, petunjuk, dan keterangan terdakwa.

Berdasarkan uraian di atas, penelitian ini bertujuan untuk mengetahui pengaturan penggunaan alat bukti website dalam penegakan hukum tindak pidana terorisme pada kasus perkara nomor 140/Pid.Sus/2018/PN.Jkt.Sel dan bagaimana kedudukan penggunaan alat bukti website dalam penanganan tindak pidana terorisme pada kasus perkara nomor 140/Pid.Sus/2018/PN.Jkt.Sel.

\section{METODE PENELITIAN}

Penelitian ini menggunakan metode penelitian eksplorasi hukum normatif. Eksplorasi hukum normatif dikonsepsikan sebagaimana yang tersirat pada peraturan perundang-undangan (law in books) maupun penelitian hukum normatif dikonsepsikan laksana tatanan atau kaidah yang menggambarkan pedoman bertingkah laku masyarakat yang dianggap pantas (Amiruddin \& Asikin, 2004). Data penelitian ini merupakan determinasi terkait dengan penggunaan alat bukti website dalam proses pembuktian yang digunakan sebagai alat bukti. Selanjutnya mana kala menunjuk ketentuan Pasal 184 ayat (1) KUHAP dan ketentuan pasal lainnya maka tidak ditemui frase atau suratan yang menyebutkan website sebagai bagian dari alat bukti sehingga melalui interpretasi dapat digunakan sebagai bagian untuk menyelesaikan kekaburan norma tersebut.

\section{HASIL DAN PEMBAHASAN}

\section{Pengaturan Alat Bukti Website dalam Penegakan Hukum Tindak Pidana Terorisme}

Determinasi menyinggung alat bukti merupakan resolusi hukum acara pidana yang bertabiat memaksa (dwingen recht),yang memiliki makna segala macam alat bukti yang menujum diatur dalam ketentuan Pasal 184 ayat (1) KUHAP tiada dapat ditambah atau dikurangi (Fuandy, 2006). Ekspansi alat bukti di Indonesia dapat disimak bersumber pada ketentuan Undang-Undang Nomor 11 Tahun 2008 Tentang Informasi Dan Transaksi Elektronik sebagaimana telah direvisi berlandaskan ketentuan Undang-Undang Nomor 19 tahun 2016 tentang Perubahan Atas UndangUndang Nomor 11 tahun 2008 tentang Informasi dan transaksi Elektronik (selanjutnya disebut UU ITE). Eksistensi UU ITE memberikan falsafah hukum perihal resistensi hukum alat bukti elektronik agar dapat diterima di persidangan. (Pengkajian: Kekuatan Nilai Pembuktian Terhadap Alat Bukti Elektronik Dalam Penanganan Tindak Pidana, 2016). Darma majelis hakim untuk bisa mensyaratkan teknis penaksiran terhadap kemampuan bukti termasuk atas informasi elektronik dan/atau pertinggal elektronik dan/atau hasil cetaknya laksana alat bukti elektronik bahwa pemastian sesorang terdakwa bersalah atau bukan dapat berlandaskan dari penilaian hakim (conviction intime)selaku subjektifitas yang tiranis untuk memastikan keterbuktian kesalahan terdakwa dan Sistem pembuktian undang-undang secara negatif (negatif wettelijk bewijstheori) yang menggabungkan antara faktor hukum positif sesuai ketentuan perundang-undangan dan faktor keyakinan hakim (Hamzah, 2001).

Serangkaian penjabaran tersebut terkhusus pada penanganan dan elaborasi tindak pidana terorisme menurut Rinaldy Amrullah dkk bahwa aksi pidana terorisme mesti ditangani seraya sungguh-sungguh dengan menghajatkan kehati - hatian sisipan, terkhusus dari birokrat penegak hokum tiada mencapai intensi berharga sepanjang memancangkan hukum salah atau disalahgunakan. Ihwal itulah memberikan rongak lain memedomani pencantuman terorisme bgaikan kejahatan yang terbilang eksklusif atau luar biasa (extra ordinary crime) (Amrullah \& dkk, 2015).

Menurut Sigid Suseno apabila merujuk pada peraturan perundang-undangan dalam tindak kejahatan distingtif bahwa instrumen petunjuk elektronik dirumuskan secara pasti dan menyandang resistensi selaku instrumen petunjuk yang absah. Pada perundang - undangan pidana umum yang mengategorikan instrumen petunjuk elektronik terpandang ada diskrepansi strategi perihal status instrumen petunjuk digital maupun instrumen petunjuk elektronik yakni pada perundang - undangan dimana 1 (satu) instrumen petunjuk elektronik diyakini laksana ekspansi instrumen petunjuk, akan tetapi dalam perundang-undangan yang berbeda diyakini laksana instrumen petunjuk yang mandiri (Suseno, 2012). Berasas dari deskripsi tersebut maka bisa disimak bahwa determinasi eksploitasi alat bukti website dapat dijadikan laksana alat bukti petunjuk mengingat situs website dapat dijadikan laksana media yang dapat memberikan suatu informasi. 


\section{Kedudukan Alat Bukti Website dalam Penanganan Tindak Pidana Terorisme Pada Kasus Perkara Nomor 140/Pid.Sus/2018/Pn.Jkt.Sel}

Instrumen petunjuk mengantongi peran yang amat esensial dalam pemeriksaan suatu perkara pidana. Suatu ihwal pidana yang ada perkakas instrumennya bakal sanggup memperlaju teknik penuntasan ihwalnya dibandingkan ihwal berbeda yang tiada ada peranti petunjuknya, lantaran dengan adanya peranti petunjuk yang diajukan dapat menambah keyakinan Hakim mengenai kealpaan dari terdakwa dan juga mampu digunakan laksana anasir memperberat atau meringankan hukuman yang akan dijatuhkan (Manope, 2017).

Adanya pengukuhan terhadap pertinggal elektronik sebagai instrumen petunjuk karena persensi keterangan elektronik dan/atau arsip elektronik mengebat dan diyakini dipergunakan instrume petunjuk yang absah untuk menghibahkan keyakinan hukum kepada pengelolaan skema elektronik dan transaksi elektronik, lebih - lebih pada pembuktian dan hal yang berkenaan dengan perbuatan hukum yang dilakukan melalui teknik elektronik. Adanya penyungguhan terhadap dokumen elektronik sebagai alat bukti dapat diketahu berdasarkan current business dalam bursa efek dan penyerasian microfiche beserta prasaran elektronik laksana peranti penyimpan arsip perusahaan. Pendayagunaan alat bukti elektronik dalam proses pembuktian dipersidangan bersumber alat bukti website dalam penegakan hukum tindak pidana terorisme pada skandal Perkara Nomor 140/Pid.Sus/2018/PN.Jkt.Sel dapat dicermati bahwah pengaplikasian alat bukti website meskipun secara dogmatis belum diatur pada ketentuan Hukum Acara Pidana khusunya Pasal 184 KUHAP, namun bercorong pedoman peradilan bahwa hakim tidak bisa menangkal untuk menjajaki dan memutus ihwal yang diajukan terhadapnya dengan kilah hukumnya tidak jelas atau tidak ada, selanjutnya kaidah hakim hendaklah membongkar arti-arti hukum lanjut dan berkelajutan di dalam konsorsium, hingga ketentuan sebagaimana dimuat dalam UU ITE yang pernah menata instrument petunjuk elektronik selaku peranti petunjuk yang absah, dapat difungsikan selaku fundamen untuk melahirkan instrumen elektronik selaku piranti petunjuk yang absah dipersidangan. Sebagaimana telah disebutkan diatas bahwa penggunaan alat bukti website sanggup dikualifikasikan selaku piranti petunjuk.

Wewenang hakim bertemperamen independen dan mandiri ketika menimang - nimang tetapan yang akan dilepaskan terhadap terdakwa. Tetapan yang menjatuhkan hukuman pemidanaan terhadap seseorang terdakwa tidak lain ketimbang tetapan yang bermuatan intruksi untuk mengadili terdakwa beracuan pada intimidasi pidana yang disebut dalam pasal yang didakwakan. Undangundang menghibahkan kemandirian terhadap hakim untuk melepaskan pidana hukuman terendah ataupun tertinggi dimana diancam dalam pidana yang berkaitan (Rusli Muhamad, 2006). Majelis hakim mengantongi kebebasan dalam memilih jenis pidana dan/atau dapat meninjau pidana yang akan dilepaskan terhadap terdakwa dalam memeriksa tindak pidana yang ditentang dan menyandang kemandirian bertujuan mematok berat ringanya pemidanaan berpedoman terhadap kealpaan terdakwa atas kelakuan yang didakwakan kepadanya terpasti sejati dan memastikan. Kitab Undang-Undang Hukum Pidana (selanjutnya disingkat KUHP) sebagaimana ditegaskan pada ketentuan Pasal 12 ayat (2) bahwa pidana penjara paling pendek yaitu 1 (satu) hari dan paling lama yaitu 15 (lima belas) tahun.Analitis KUHAP pada determinasi Pasal 183 ditegaskan bahwa Hakim tiada dapat menggulingkan pidana terhadap seseorang kecuali manakala dengan seminimumnya 2 (dua) piranti petunjuk yang absah dia menyabet ketetapan hati bahwa suatu tindak pidana sungguh-sungguh terjadi dan bahwa terdakwalah yang bersalah melakukannya. Serta pada ketentuan Pasal 193 ditegaskan andaikan pengadilan beranggapan sekiranya terdakwa bersalah menggarap tindak pidana yang dilepaskan terhadapnya, hingga pengadilan melepaskan pidana.

\section{SIMPULAN DAN SARAN}

\section{Simpulan}

Berdasarkan hasil penelitain yang telah dijabarkan di atas, maka dapat disimpulkan bahwa harmonisasi eksploitasi alat bukti website pada pengukuhan hukum tindak pidana terorisme pada kasus perkara nomor 140/Pid.Sus/2018/PN.Jkt.Sel yang manakala menunjuk pada determinasi Pasal 184 KUHAP maka bahan elektronik tak tergolong ke dalam klasifikasi piranti petunjuk yang absah. Akan tetapi semisal berpatokan pada peraturan perundang-undangan dalam tindak pidana khusus maka media bukti elektronik mengantongi resistensi sebagai alat bukti yang sah, hal ini dapat dilihat berfalsafah ketentuan Pasal 5 ayat (1) UU ITE yang dipertegas kembali pada bunyi ketentuan Pasal 
44 UU ITE. Dengan demikian status petunjuk elektronik mencorakkan piranti petunjuk yang independen serta mewujudkan pengembangan atas piranti petunjuk yang absah selayaknya ditata di hukum acara pidana yang valid di Indonesia, sampai sanggup diaplikasikan selaku piranti petunjuk di persidangan. Kemudian, konstruksi pemakaian piranti petunjuk website atas penggarapan tindak pidana terorisme dalam kasus ihwal nomor 140/Pid.Sus/2018/PN.Jkt.Sel, bersendikan kaidah yustisi bahwasanya hakim tidak dapat menampik demi meneliti dan menginterupsi ihwal yang diajukan terhadapnya kendatipun atas kuasa hukumnya tiada nampak alias tiada, dan kaidah bahwa hakim hendaklah mengusut nilai-nilai hukum yang timbul dan meruak-ruak di dalam masyarakat, maka determinasi sebagaimana diatur dalam UU ITE yang pernah mendikte petunjuk elektronik selaku piranti petunjuk yang absah, mampu diaplikasikan selaku fundamen untuk mendaulat petunjuk elektronik selaku piranti petunjuk yang absah dipersidangan.

\section{Saran}

Selain dari simpulan penelitian ini, adapun beberapa saran yang hendak disampaikan ke berbagai pihak yakni pemerintah; supaya melenggekkan regulasi atau meligat diskusi pengkajian RKUHP khusunya terkait dengan piranti petunjuk sehingga piranti petunjuk diluar determinasi Pasal 184 KUHAP dapat segera diatur secara tegas, mengingat alat bukti menyandang peranan yang sangat penting dalam eksplorasi suatu perkara termasuk pada penanganan perkara pidana. Selanjutnya, kepada majelis hakim; supaya menggali kebenaran persidangan dengean efektif terhadap hal-hal yang memiliki keterkaitan secara langsung ataupun tidak langsung dengan tindak pidana terorisme sehingga putusan yang dijatuhkan terhadap terdakwa dapat berlaku maksimal dan memberi efek jera, selanjutnya terhadap masyarakat diharapkan untuk memilihak dan/atau memilih untuk melihat, mendengar ataupun membaca segmen - segmen dari strategi terorisme baik dalam bentuk media cetak atau elektronik serta ucapan- ucapan yang dapat memberikan informasi menyesatkan sehingga tidak dengan mudah terjerumus untuk melakukan tindak pidana terorisme.

\section{DAFTAR PUSTAKA}

Adji, I. S. (2001). Terorisme dan HAM dalam Terorisme: Tragedi Umat Manusia. O.C Kaligis \& Associates.

Amiruddin, \& Asikin, Z. (2004). Pengantar Metode Penelitian Hukum. PT. RajaGrafindo Persada. Amrullah, R., \& dkk. (2015). Tindak Pidana Khusus Diluar KUHP. Justice Publisher.

Fuandy, M. (2006). Teori Hukum Pembuktian (Perdata dan Pidana). Citra Aditya Bhakti.

Hamzah, A. (2001). Bunga Rampai Hukum Pidana dan Acara Pidana. Ghalia Indonesia.

Pengkajian: Kekuatan Nilai Pembuktian terhadap Alat Bukti Elektronik dalam Penanganan Tindak Pidana, (2016).

Manope, I. J. (2017). Kekuatan Alat Bukti Surat Elektronik dalam Pemeriksaan Perkara Pidana. Lex Crimen, 6(2), 107-113.

Marbun, S. F. (2003). Peradilan Tata Usaha Negara. Liberty.

Suseno, S. (2012). Yurisdiksi Tindak Pidana Siber. Refika Aditama. 